medRxiv preprint doi: https://doi.org/10.1101/2021.03.31.21254662; this version posted April 6, 2021. The copyright holder for this preprint (which was not certified by peer review) is the author/funder, who has granted medRxiv a license to display the preprint in perpetuity. It is made available under a CC-BY-NC-ND 4.0 International license .

\title{
Leveraging Health Systems Data to Characterize a Large Effect Variant Conferring Risk for Liver Disease in Puerto Ricans
}

Gillian M. Belbin ${ }^{1,2}$, Stephanie Rutledge ${ }^{2}$, Tetyana Dodatko ${ }^{3}$, Sinead Cullina ${ }^{1}$, Michael C. Turchin ${ }^{1}$, Sumita Kohli ${ }^{1}$, Denis Torre ${ }^{3}$, Muh-Ching Yee ${ }^{4}$, Christopher R. Gignoux ${ }^{5}$, Noura S. AbulHusn $^{1,2,3}$, Sander M. Houten ${ }^{3}$, Eimear E. Kenny ${ }^{1,2,3}$

1. Institute for Genomic Health, Icahn School of Medicine at Mount Sinai, New York, NY, USA

2. Department of Medicine, Icahn School of Medicine at Mount Sinai, New York, NY, USA

3. Department of Genetics and Genomic Sciences, Icahn School of Medicine at Mount Sinai, New York, NY, USA

4. Stanford Functional Genomics Facility, Stanford University, Stanford, CA, USA

5. Colorado Center for Personalized Medicine, University of Colorado Anschutz Medical Campus, Aurora, CO, USA

\footnotetext{
Abstract

Broad-scale adoption of genomic data in health systems offers opportunities for extending methods for the discovery of variation linked to underlying genomic disease risk. We applied a population-scale linkage mapping approach in a large multi-ethnic biobank to a spectrum of disease outcomes derived from Electronic Health Records (EHRs) and uncovered a risk locus for liver disease. We used genome sequencing and in silico approaches to fine-map the signal to a non-coding variant (c.2784-12T>C) in the gene $A B C B 4$. In vitro analysis confirmed the variant disrupted splicing of the ABCB4 pre-mRNA. Four of five homozygotes had evidence of advanced liver disease, and there was a significant association with liver disease among heterozygotes, suggesting the variant is linked to increased risk of liver disease in an allele dose-dependent manner. Population-level screening revealed the variant to be at a carrier rate of $1.95 \%$ in Puerto Rican individuals, likely as the result of a Puerto Rican founder effect. This work demonstrates that integrating EHR and genomic data at a population-scale can facilitate novel strategies for understanding the continuum of genomic risk for common diseases, particularly in populations underrepresented in genomic medicine.
} 
medRxiv preprint doi: https://doi.org/10.1101/2021.03.31.21254662; this version posted April 6, 2021. The copyright holder for this preprint (which was not certified by peer review) is the author/funder, who has granted medRxiv a license to display the preprint in perpetuity. It is made available under a CC-BY-NC-ND 4.0 International license .

\section{Introduction}

Genetic identification of monogenic disease historically relied on tracking the co-segregation of genomic segments and disease-state through familial pedigrees, in a process known as linkage mapping $[1,2]$. This approach is typically followed by localized sequencing to reveal the disease causing variant and confirmatory functional studies in vitro or in animal models. This strategy has been used successfully throughout the late 20th century to uncover thousands of loci underlying suspected, rare genetic disorders[3]. More recently, next generation sequencing technologies have led to the identification of the genetic etiology of disease through the direct sequencing of patient exomes and genomes in close pedigree structures[4]. Genomic technologies have also been applied in health systems to uncover unknown pathogenic variants and streamline diagnosis[5] and to refine our understanding of the penetrance and frequency of pathogenic variants at a population-level[6]. However, the preponderance of genome sequencing and genomic medicine research have been performed in populations of European descent, and there is a lag in genomic sequence data available for, and studies directed at, understanding monogenic disorders in non-European populations[7].

The growth of large-scale biobanks linked to health systems data in recent years has opened new avenues to uncovering the etiology of known and novel monogenic disorders[8]. With some exceptions[9][10], the majority of genomic data generated in biobanks worldwide is on low-cost genotype arrays rather than genome sequencing and many biobanks are designed for populationbased recruitment rather than being disease or pedigree focused. However, by leveraging array data in population-based biobanks, it is possible to calculate haplotypes of the genome that have been co-inherited from a recent common ancestor Identical-by-Descent (IBD)[11]. Using this strategy, genealogical relationships can be captured locally along the genome among distantly, or putatively unrelated members of a population, which are particularly enriched in founder populations[12-14][15]. IBD-haplotypes have the potential to harbour rare alleles that are not directly ascertained on genotyping arrays, facilitating association mapping of rare variants even when they are not directly observed[12], or are too rare or population-private to be readily imputable with currently existing reference panels; this approach is known as population-scale linkage or IBD-mapping[15,16]. This property of IBD makes it especially useful for rare variant based associations in diverse and understudied founder populations, for which deep genome sequencing datasets may not be available. Furthemore, previous studies have leveraged EHR 
medRxiv preprint doi: https://doi.org/10.1101/2021.03.31.21254662; this version posted April 6, 2021. The copyright holder for this preprint (which was not certified by peer review) is the author/funder, who has granted medRxiv a license to display the preprint in perpetuity. It is made available under a CC-BY-NC-ND 4.0 International license .

data in concert with genomic data to demonstrate the ubiquity and potential under-recognition of monogenic forms of disease in patient populations[6,17]. We previously applied IBD-mapping to height in a Puerto Rican (PR) founder population in New York City and identified a monogenic variant underlying the skeletal disorder Steel Syndrome[18], demonstrating the power for discovery of monogenic variants underlying monogenic disorders.

Here we expand our previous approach by systematically associating IBD haplotypes with the full spectrum of EHR derived phenotypes in the large founder population of PR and PR descent participants in the diverse, multi-ethnic BioMe biobank in New York City. We performed a Phenome-Wide Association Study (PheWAS)[19] of IBD-haplotypes under a recessive model in the PR founder population and identified a significant association between homologous IBD sharing at the locus 7q21.12 and severe liver disease. Fine-mapping of the IBD-haplotypic region uncovered a rare variant in $A B C B 4$ ( $A B C B 4: C .2784-12 T>C$; rs201498350), a gene known to play a causal role in multiple forms of hepatobiliary disease[20]. In vitro analysis demonstrated that this variant disrupted splicing, leading to an ABCB4 protein product lacking exon 23. Manual chart review of these patients revealed evidence of severe liver diseases in four of five homozygotes. We also investigated the impact of harboring one copy of $c .2784-12 T>C$ via a combination of PheWAS, analysis of liver function tests, and manual chart review, revealing an increased risk of liver disease in heterozygotes. Furthermore, population-level screening revealed the variant to be common in PR (carrier rate of $\sim 1.9 \%$ ), while rare $(<1 \%)$ in other global populations. These analyses provide a methodological framework for bridging statistical genetics and clinical genomics, and demonstrate that EHR-embedded, population-level research can elucidate the continuum of genomic risk for liver disease.

\section{Results}

\section{Inference of Identity-by-Descent Haplotypes in PR population}

We previously inferred Identity-by-Descent (IBD) sharing across BioMe and used IBD haplotypes to cluster patients into communities linked by recent shared ancestry, as described in Belbin et al. 2019[21]. By using this method, we identified a community of individuals of Puerto Rican (PR) ancestry, and observed elevated IBD sharing within this group, suggestive of a founder effect. We clustered IBD haplotypes locally along the genome by homology and identified 4526956 homologous IBD-clusters within the PR population. Examining the frequency spectrum of these haplotypic alleles, we observed most to be rare (median haplotypic frequency $=0.04 \%$, 
medRxiv preprint doi: https://doi.org/10.1101/2021.03.31.21254662; this version posted April 6, 2021. The copyright holder for this preprint (which was not certified by peer review) is the author/funder, who has granted medRxiv a license to display the preprint in perpetuity. It is made available under a CC-BY-NC-ND 4.0 International license .

Supplementary Figure 1). We hypothesized that we may be able to leverage these haplotypic alleles as proxies for unobserved rare variants in an association testing framework designed for discovery of monogenic recessive disorders (Figure 1).

\section{Phenome Wide Association of Identity-by-Descent Haplotypes in Puerto Rican Community}

To systematically explore the relationship between haplotypic alleles and EHR derived health outcomes, we performed a PheWAS under a recessive model implementing the Saddle Point Approximation, which accommodates for rare observations and instances of extreme case-control imbalance. Because our method depends on leveraging cryptic relatedness, we applied our approach specifically within PR BioMe participants, on the basis of previous observations of a founder effect within this group [18]. In our model, the haplotypic alleles served as the primary predictor variable and ICD-9 billing codes served as the outcome variable. We restricted analysis to 754 haplotypic alleles for which there were at least 3 observations of individuals that were homozygous for a shared IBD haplotype, and systematically tested these for association against each ICD-9 code ( $n=3,679,520$ tests in total). Only one association achieved study-wide significance (SWS, threshold: $p<1.4 \times 10^{-8}$ ), an association at a haplotypic allele at $7 q 21.12$ $\left(p<2.9 \times 10^{-9}\right.$, haplotypic frequency=0.7\%) (Figure 2A). The significant haplotypic allele represented 3 individuals who were each homozygous for a homologous segment of IBD at the region, and all of whom had EHR record of the rare ICD-9 code "571.6" (which encodes for "Biliary Cirrhosis"). While not study-wide significant, the haplotypic allele was also associated with the ICD-9 code "576.1" (which encodes for 'cholangitis'; $p<9.9 \times 10^{-8}$ ). In addition to the three individuals who were homozygous for the IBD haplotype at 7q21.12, N=70 individuals carried the haplotype in the heterozygous state. The significant haplotypic allele spanned a large interval (minimum shared boundary: chr7:86,817,459-90,407,237) (Figure 2B) and contained 21 known genes.

Fine-mapping IBD-haplotypic signal uncovers a cryptic splice variant in ABCB4

To finemap the signal we performed whole genome sequencing of all three homozygous carriers, and characterized variants that fell within the minimum shared boundary of the haplotypic allele. Under the hypothesis that the causal variant would be rare we filtered to retain only variants with a global minor allele frequency of $<1 \%$ (in any population group from gnoMAD or 1000 Genomes; Supplementary Table 1). We identified a total of 195 that were shared in the homozygous state between all three individuals, none of which represented non-synonymous coding variation. We found 24 sites homozygous in all three individuals that were also present in ClinVar 
medRxiv preprint doi: https://doi.org/10.1101/2021.03.31.21254662; this version posted April 6, 2021. The copyright holder for this preprint (which was not certified by peer review) is the author/funder, who has granted medRxiv a license to display the preprint in perpetuity. It is made available under a CC-BY-NC-ND 4.0 International license .

(Supplementary Table 2). Intersecting this list with the allele frequency data, only one variant had a MAF of < 1\% across all population databases, a single nucleotide variant (rs201498350, NM_000443.4(ABCB4):C.2784-12T>C); this variant had been asserted as "Likely Pathogenic" for "progressive familial intrahepatic cholestasis, type 1" (PFIC1) by a single submitter. The ABCB4:C.2784-12T>C variant has a CADD[22] score of 15.9, and a spliceAI[23] score of 0.39 (interpreted as the probability of causing a splice acceptor loss). This variant occurs in a polypyrimidine tract $12 \mathrm{bp}$ from the 3 ' splice site of intron 22. The natural occurrence of $A B C B 4$ mRNAs (NM_018850.2) that lack exon 23 indicates that this splice site is weak and prone to exon skipping. This is further supported by our observation when examining HEK-293 cells tha ABCB4 cDNA fragments are expressed both with and without exon 23 (supplementary figure 2). Skipping of exon 23 leads to a $141 \mathrm{bp}$ deletion and likely encodes for a non-functional protein due to the deletion of 47 amino acids (929 to 975), which encompasses the majority of transmembrane helix 11 and the last extracellular loop.

In vivo analysis of ABCB4:C.2784-12T>C indicates it causes increased skipping of exon 23 To test whether $A B C B 4: c .2784-12 T>C$ affects splicing of exon 23, we cloned a genomic region of $A B C B 4$ containing exons 22 to 24 in an expression vector and expressed this fragment in HEK293 cells (Figure 3). RT-PCR shows that the resulting pre-mRNA fragment is spliced into mRNA with and without exon 23. In this assay, the mRNA without exon 23 is more abundant than the mRNA with exon 23. Mutating the consensus $T$ at the -12 position of intron 22 into the less-favored pyrimidine $C$ further decreases splicing efficiency at this acceptor site. Mutating it to the purine $G$ appears to prevent splicing completely. Our results show that the splice acceptor site of intron 22 is weak, and that the c.2784-12T>C variant increases skipping of exon 23 .

\section{Clinical characterization of ABCB4:c. 2784-12T>C in homozygotes}

Subsequent to the discovery of the c.2784-12T>C variant, we obtained exome sequencing data for a larger dataset of unrelated BioMe participants $(\mathrm{N}=28,344)$. This included $N=4332$ PR participants who were in the original discovery dataset, and $\mathrm{N}=1015$ independent PR participants. Leveraging off-target exome sequencing reads in the independent dataset, we identified two additional participants who were homozygous for the c.2784-12T>C variant. A subject domain expert performed manual chart review of all five homozygotes. Evaluation of outpatient measures of serum liver enzyme levels and liver function tests revealed significant elevation of measures consistent with liver disease (Table 1). Four of the five homozygotes were found to have a diagnosis of cirrhosis on chart review, and the fifth had liver steatosis on imaging. Each 
medRxiv preprint doi: https://doi.org/10.1101/2021.03.31.21254662; this version posted April 6, 2021. The copyright holder for this preprint (which was not certified by peer review) is the author/funder, who has granted medRxiv a license to display the preprint in perpetuity. It is made available under a CC-BY-NC-ND 4.0 International license .

homozygote had a distinct etiology of their liver disease: alcohol-associated cirrhosis, primary sclerosing cholangitis, primary biliary cholangitis (with possible component of alcohol-associated liver disease) and cryptogenic cirrhosis. Two had undergone liver transplant and one was found to have an incidental hepatocellular carcinoma on explant.

\section{Clinical Characterization of ABCB4:c.2784-12T>C in Heterozygotes}

Variation in $A B C B 4$ is known to confer susceptibility to hepatobiliary disease via both autosomal dominant $(A D)$ and autosomal recessive $(A R)$ modes of inheritance, and with variation in severity of disease[27],[28]. To clinically characterize the $C .2784-12 T>C$ variant in heterozygotes, we identified via exome sequence data $\mathrm{N}=73$ PR participants in the original discovery dataset (of which $\mathrm{N}=50$ were carriers of the discovery IBD haplotype which has $75 \%$ concordance with the causal variant, Supplementary Table 3)), and $\mathrm{N}=11$ in the independent dataset of PR participants, for a total of $\mathrm{N}=84 \mathrm{PR}$ heterozygotes. We compared this cohort to clinical data for $\mathrm{N}=5248$ PR participants who did not harbor the $c .2784-12 T>C$ variant. To test for evidence of liver and other phenotypes in heterozygous carriers of $A B C B 4: C .2784-12 T>C$, we performed a PheWAS of ICD-9 codes. While no association achieved study-wide significance, the ICD-9 "574.10", which encodes for "Calculus of gallbladder with other cholecystitis, without mention of obstruction" was ranked second among all associations $(p<0.002$; odds ratio=7.1; SE=1.9; Table 2). We also explored the relationship between $A B C B 4: C .2784-12 T>C$ and nine outpatient serum liver enzyme levels and liver function tests in heterozygous carriers. We extracted these measures (Supplementary Figure 3) and performed linear regression of $A B C B 4:$.2784-12T>C carrier status versus the nine laboratory measures, adjusting for age and sex (Table 3). Both alanine aminotransferase (ALT) and aspartate transaminase (AST) were significantly elevated among carriers $(p<0.0007$ (beta=0.39; SE=0.21) and $p<0.002$ (beta=0.36; SE=0.21), respectively) after adjusting for multiple testing (study-wide significance threshold $p<0.0056$ ), while the association between $A B C B 4:$ c.2784-12T>C carrier status and elevated gammaglutamyl transferase (GGT) achieved nominal significance $(p<0.03)$. To follow up these findings, we further evaluated the association of $A B C B 4: c .2784-12 T>C$ with liver disease phenotypes by performing manual chart review of $50 A B C B 4: c .2784-12 T>C$ carriers and 50 age-, sex-, and ancestry-matched non-carriers. We excluded 14 subjects with viral hepatitis from further analysis. Medical records from the remaining 43 carriers and 43 non-carriers were reviewed for evidence of any non-viral liver disease by a physician blinded to subjects' $A B C B 4$ carrier status. A total of 18 of 43 carriers ( $41.9 \%$ ) had evidence of liver disease, compared to 8 of 43 non-carriers (18.6\%; $p=0.03, O R=3.01$ ). Together with the findings of advanced liver disease in homozygotes, this 
medRxiv preprint doi: https://doi.org/10.1101/2021.03.31.21254662; this version posted April 6, 2021. The copyright holder for this preprint (which was not certified by peer review) is the author/funder, who has granted medRxiv a license to display the preprint in perpetuity. It is made available under a CC-BY-NC-ND 4.0 International license .

suggests that $A B C B 4:$.c. $2784-12 T>C$ is associated with increased risk of liver disease in an allele dose-dependent manner.

\section{Population History and Global Distribution of ABCB4:C.2784-12T>C}

Finally, to gain a better understanding of which populations may harbor the ABCB4:C.2784-12T>C risk variant, we leveraged complete survey information on ethnicity and geographical origin. One homozygote reported being born in Puerto Rico, while the remaining four self-reported being born on the US mainland. By exploring segregation based on self-reported country of birth and selfreported ethnicity, we observed that $\mathrm{N}=42$ carriers reported being born in PR (out of $\mathrm{N}=2251 \mathrm{PR}$ born individuals in total), suggesting a carrier rate of $1.95 \%$ in PR (Figure 4A). The remaining $\mathrm{N}=42$ carriers reported being born on the US mainland, with 40 self-identifying as Hispanic/Latino (carrier rate of $1.36 \%$ ). Three carriers reported being born in the Dominican Republic, one reported being born in Barbados, and the remaining two self-identifying as European American. Examination of local ancestry along the maximum shared boundary of IBD sharing between the three original homozygotes revealed all to be homozygous for European ancestry across the locus (Figure 4B). Additionally, the variant is present in 27 copies in the gnomAD(v3.1)[24,25] database, at a minor allele frequency of $0.16 \%$ among the "Latino/Admixed American" population, and with a single copy being present in each of the "Other", "African/African American", and "European (non-Finnish)" populations. We also identified a total of $\mathrm{N}=165$ carriers in the UK Biobank dataset, $\mathrm{N}=163$ of which self-identified as "White", and the remaining two did not report an ethnicity in the survey. Examining carriers by country of origin, we noted that the majority selfreported being born in European countries with the highest carrier rate in Austria (0.5\%) and lowest in England (0.03\%) (Table 4). Overall this suggests that $A B C B 4: C .2784-12 T>C$ is segregating at very low frequency in European populations, and arose to higher frequency in the PR population due to a founder effect on the European ancestral background[26].

\section{Discussion}

Here we demonstrate that by using IBD sharing to leverage distant genealogical relationships in a patient population, and by linking this to a breadth of phenotypes derived from an EHR, it is possible to discover monogenic forms of disease segregating appreciably in a large founder population. By applying this method to the BioMe PR population, we uncover a genomic signal associated with liver disease. As we have previously shown, PRs represent an understudied 
medRxiv preprint doi: https://doi.org/10.1101/2021.03.31.21254662; this version posted April 6, 2021. The copyright holder for this preprint (which was not certified by peer review) is the author/funder, who has granted medRxiv a license to display the preprint in perpetuity. It is made available under a CC-BY-NC-ND 4.0 International license .

founder population with elevated levels of cryptic relatedness, making IBD based approaches for genomic discovery especially powerful within this population.

We fine-mapped the novel signal to a non-coding variant in the $A B C B 4$ gene ( $A B C B 4:$ :C.2784$12 \mathrm{~T}>\mathrm{C})$. We demonstrated that this variant disrupts splicing in vitro, resulting in an mRNA lacking exon 23 and most likely encoding a non-functional protein product. $A B C B 4$ encodes for the ATP binding cassette subfamily $B$ member 4 (ABCB4), also known as multi-drug resistance protein 3 (MDR3) [29]. The protein is expressed on the canalicular membrane of hepatocytes, and is involved in the secretion of phosphatidylcholine[30], an essential component of bile, into the bile canaliculus. This role mitigates the potentially damaging effect of bile salt on the hepatocellular membrane [31,32]. Homozygous knockout mice for the murine ortholog, $A b c b 4$, exhibit hepatocellular inflammation and necrosis, as well as damage to the bile ducts [31]. In humans, variation in $A B C B 4$ has previously been implicated in numerous forms of hepatobiliary and other liver related phenotypes [33]. Pathogenic variation in $A B C B 4$ is causal for progressive intrahepatic familial cholestasis type 3 (PFIC3) [34-36], a severe autosomal recessive hepatobiliary disease that typically affects children and adolescents [28]. Notably, ABCB4 has also previously been implicated in cryptogenic cirrhosis of the liver [37]-[38], as well as a range of milder phenotypes including intrahepatic cholestasis of pregnancy [39],[40-42], drug induced liver injury[43], and low phospholipid-associated cholelithiasis[44]. The range of Mendelian ABCB4 associated phenotypes has been noted to follow both autosomal dominant and recessive modes of inheritance. Furthermore, in large-scale population-based studies, variation in $A B C B 4$ has been statistically associated with elevated risk for a number of liver-related phenotypes, including risk for non-alcoholic fatty liver disease[45], elevated serum liver enzyme levels[46,47], and risk for hepatobiliary carcinoma[48], suggesting that common variation in this gene may play a broader role in liver disease risk in the human population.

A previous clinical study of PR ancestry patients with PFIC noted a high prevalence of symptoms representative of $\mathrm{ABCB} 4$ deficiency, and suggested an $A B C B 4$ founder variant may contribute to the prevalence of PFIC in the PR population [49]. We observe that $A B C B 4: c .2784-12 T>C$ segregates at a carrier rate of $1.95 \%$ in PR ancestry individuals, while being rare or absent in non-Caribbean populations, highlighting the importance of including individuals of diverse ancestry in genomic research. The high carrier rate in PR suggests the existence of hundreds of homozygous individuals who may be at elevated risk for liver disease. We identified five homozygotes for ABCB4:c.2784-12T>C in the Mount Sinai health system, and found evidence of 
medRxiv preprint doi: https://doi.org/10.1101/2021.03.31.21254662; this version posted April 6, 2021. The copyright holder for this preprint (which was not certified by peer review) is the author/funder, who has granted medRxiv a license to display the preprint in perpetuity. It is made available under a CC-BY-NC-ND 4.0 International license .

liver cirrhosis in four. The etiology of liver disease in each was noted to be different, which suggests that $A B C B 4:$ C.2784-12T>C could predispose to various forms of liver disease. We also noted significant elevation of liver enzyme levels in heterozygotes, as well as increased rates of liver diseases in heterozygotes compared to matched non-carriers. This suggests that heterozygous carriers of this variant are also at risk for liver disease. This is consistent with the known $A D$ and $A R$ inheritance of other $A B C B 4$ variants. Taken together, this work demonstrates the utility of genetics-first approaches to discovery in health systems for uncovering a continuum of genomic risk for common diseases. Understanding such genetic risk factors at an individual level will be useful in clinical risk stratification and care in the future.

\section{Methods}

\section{BioMe Biobank}

Study participants were recruited from the BioMe Biobank Program of The Charles Bronfman Institute for Personalized Medicine at Mount Sinai Medical Center from 2007 onward. The BioMe Biobank Program (Institutional Review Board 07-0529) operates under a Mount Sinai Institutional Review Board-approved research protocol. All study participants provided written informed consent.

\section{Genotype Data and Quality Control}

Genotyping, quality control and merging of array data across the OMNI and MEGA platforms was performed as described in detail in Vishnu et al. 2019 [50]. In brief, we performed standard quality control for variants based on missingness, heterozygosity, and Hardy Weinberg equilibrium using PLINKv1.9 [51,52]. We removed samples that were duplicated across both arrays and subset data to the intersect of variants present on both platforms ( $n=461,677$ SNPs; $n=21,692$ individuals). After subsequently removing palindromic sites with a missingness rate of $>1 \%$, this resulted in a total of 377,799 SNPs and 25,750 individuals for downstream analysis.

\section{Haplotype Phasing}

Phasing was performed per chromosome with the EAGLEv2.0.5[53] software using the genetic map (hg19) that is included in the EAGLEv2.0.5 package (url: https://data.broadinstitute.org/alkesgroup/Eagle/downloads/Eagle v2.0.tar.gz).

An additional 2 individuals were excluded during the phasing process if they had a per chromosome level missingness rate of greater than $10 \%$ for any one autosome, leaving $\mathrm{N}=25,748$ individuals in total. 
medRxiv preprint doi: https://doi.org/10.1101/2021.03.31.21254662; this version posted April 6, 2021. The copyright holder for this preprint (which was not certified by peer review) is the author/funder, who has granted medRxiv a license to display the preprint in perpetuity. It is made available under a CC-BY-NC-ND 4.0 International license .

\section{Identity-by-Descent Inference and Quality Control}

Phased output from EAGLE was filtered to a MAF of $>=1 \%$ and converted to PLINK format using fCGENE [54]. This was used as input for the GERMLINE algorithm [55]. We ran GERMLINE over each autosome across all individuals simultaneously using the following flags: "-min_m 3 err_hom 0 -err_het 2 -bits 25 -haploid." For quality control, IBD that overlapped with low complexity regions were excluded, along with IBD that fell within regions of excessive IBD sharing (which we defined as regions of the genome where the level of pairwise IBD sharing exceeded 3 standard deviations above the genome-wide mean).

Identity-by-descent based clustering of Puerto Rican ancestry participants

We summed IBD haplotypes along the genome of all $\mathrm{N}=25748$ participants and used to construct an adjacency matrix where each node represented a BioMe participant and each weighted edge represented the pairwise sum of IBD sharing between a given pair of individuals. After first excluding edges sharing $>=1500 \mathrm{cM}$ of their genome IBD, we employed the InfoMap[56,57] as implemented in the iGraph package ( $R$ version 3.2.0) to uncover communities of individuals enriched for IBD sharing. We uncovered a community of $\mathrm{N}=5100$ individuals who, based on selfreporting labels, we defined as the Puerto Rican ancestry IBD-community going forward.

\section{Phenome Wide Association of Identity-by-Descent Haplotypes}

We first clustered IBD haplotypes inferred via GERMLINE into homologous cliques using the DASH [58] advanced (dash_adv) algorithm across all BioMe participants, including the following additional parameters: “-win 250000 -r2 1". We then extracted the Puerto Rican community $(n=5100)$ from the DASH output and recoded individuals who were homozygous for a given IBD clique as " 1 " and those who were heterozygous or who were not members of the clique as " 0 ". We then used this as the primary predictor variable for an IBD-based Phenome Wide Association that was modeled using an implementation of the Saddle Point approximation[59] (using the R package "SPAtest", R version 3.2.0), with age and sex included as covariates. For each test, one individual from each pair of directly related individuals was excluded prior to association, preferentially excluding 'controls' to 'cases' for each ICD-9 code.

\section{Whole Genome Sequencing, Variant Calling and Annotation of IBD Homozygotes}

Alignment and variant calling of Whole Genome Sequence (WGS) data was performed using the pipeline provided by Linderman et al.[60]. Further variant annotation was performed using Variant 
medRxiv preprint doi: https://doi.org/10.1101/2021.03.31.21254662; this version posted April 6, 2021. The copyright holder for this preprint (which was not certified by peer review) is the author/funder, who has granted medRxiv a license to display the preprint in perpetuity. It is made available under a CC-BY-NC-ND 4.0 International license .

Effect Predictor. These annotations were then intersected the WGS data for the three homozygotes using an in-house python script.

Phenome Wide Association of ABCB4:C.2784-12T>C in heterozygous carriers

A Phenome-wide association of $A B C B 4: c .2784-12 T>C$ carrier status was conducted using the SAIGE software[50,61] for a total of $n=4903$ Puerto Rican ancestry participants (homozygous individuals were excluded). ICD-9 billing codes served as the phenotypic outcome, and we included age, sex and the first five principal components (PCs) as covariates, as well as a General Relatedness Matrix (GRM) to account for relatedness. The association analysis was restricted to ICD-9 codes for which 3 or greater cases were present among carriers ( $N=550$ ICD-9 codes).

\section{Association of ABCB4:C.2784-12T>C and Liver Enzymes}

Outpatient values for nine laboratory tests for liver enzymes and liver function were extracted from EHRs. For each individual, the median value was taken for each trait. Patients were stratified according to sex, and outliers that fell greater than 4 standard deviations from the sex-specific population median were excluded. Sex-specific values were subsequently log-transformed, and converted to $z$-scores (mean 0 , standard deviation 1) before the data was recombined. These $z-$ scores were then used as the phenotypic outcome in a linear model that included age as a covariate. Related individuals were excluded from the analysis, as were the five individuals who were homozygous for the $A B C B 4: c .2784-12 T>C$ variant.

\section{Association of ABCB4:C.2784-12T>C and Liver Disease}

Manual chart review was performed by a physician blinded to the subject's ABCB4 carrier status. Subjects with hepatitis $C$ causing viral hepatitis were excluded from further analyses. Text search was done for "liver disease", "fatty liver", "NAFLD", "fibrosis", "steatosis", "sclerosing cholangitis", and "cirrhosis". A review of all prior abdominal imaging was performed, specifically assessing for phrases such as "nodular" or "hyperechogenic" liver. If any of these searches yielded a positive result, then clinical notes, alcohol history, BMI, liver function tests, FibroScan results, and any liver biopsies were reviewed to establish the etiology and severity of the subject's liver disease. A two-tailed Fisher's exact test was performed to assess for associations between carrier status and the presence of any non-viral liver disease, and a P-value of $<0.05$ was considered significant. 
medRxiv preprint doi: https://doi.org/10.1101/2021.03.31.21254662; this version posted April 6, 2021. The copyright holder for this preprint (which was not certified by peer review) is the author/funder, who has granted medRxiv a license to display the preprint in perpetuity. It is made available under a CC-BY-NC-ND 4.0 International license .

Functional validation of $A B C B 4: C .2784-12 T>C$

We amplified (PrimeSTAR GXL DNA Polymerase, Takara Bio) and cloned a 4,340bp ABCB4 genomic region from exons 22 to exons 24 into the pCR2.1-TOPO vector (TOPO TA cloning kit, Invitrogen) using the following forward and reverse primers: 5'-GCGATCGCC ATG GTG TCT TTG ACC CAG GAA AGA AA-3' and 5'-ACG CGT AGA ACT GGC ATG TCC TAG AGC C-3'. Sequence verified pCR2.1-TOPO with this fragment was used as a template to re-amplify the insert (PrimeSTAR GXL DNA Polymerase, Takara Bio) using the following forward and reverse primers: 5'-CAC TTG GCG ATC GCC ATG GTG TCT TTG ACC CAG GAA AGA A-3' and 5'-GAT AAC ACG CGT AGA ACT GGC ATG TCC TAG AGC C-3'. The primers introduce a 5' AsiSI/Sgfl and 3' Mlul restriction site (bold and underlined) that were used for cloning the fragment into the pCMV6-entry vector (Origene). The c.2784-12T>C variant was introduced using site-directed mutagenesis (Q5 Site-Directed Mutagenesis kit, NEB) with the following oligonucleotides primers: Q5-Fw 5'-AGTATACTGACTTGCTTTTCAG-3' (mutated nucleotide in lower case) and Q5-Rev 5'TGTAACCATCTCTTCAGC-3'. The wild type and variant pCMV6-ABCB4 were sequenced to confirm the absence and presence of the variant. Both vectors were transfected into HEK-293 cells using Lipofectamine 2000. After 24 hours, cells were lysed in QIAzol and RNA isolated (RNeasy mini kit, QIAGEN). RNA was used for cDNA synthesis (SuperScript IV First-strand Synthesis System, Invitrogen) after which the splicing of exons 22-24 was studied using PCR. Because HEK-293 cells express low levels of native $A B C B 4$, we used the forward primer annealing in exon 22 used for cloning and a reverse primer on the MYC-DDK tag of the pCMV6 vector: DDK reverse 5'-CCT TAT CGT CGT CAT CCT TGT AAT CC-3'. All PCR fragments were Sanger sequenced to confirm their identity.

\section{Main Figures}

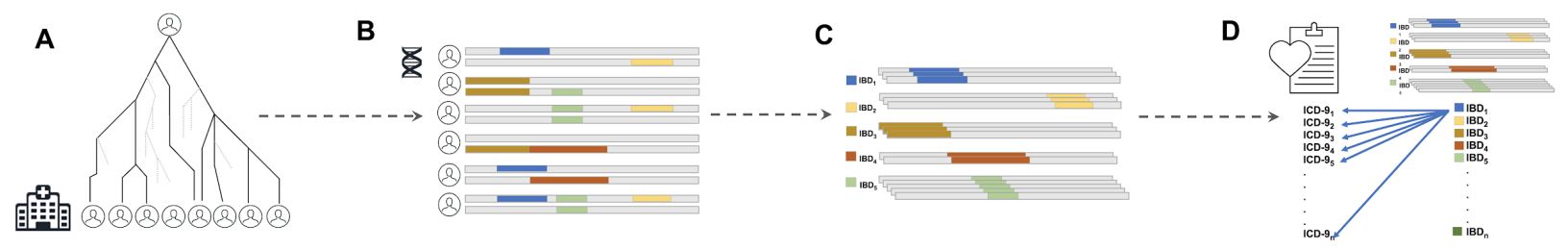

Figure 1. Framework for population scale linkage analysis in a health system. A) Distant, cryptic genealogical relationships are present in large, putatively unrelated patient populations. 
medRxiv preprint doi: https://doi.org/10.1101/2021.03.31.21254662; this version posted April 6, 2021. The copyright holder for this preprint (which was not certified by peer review) is the author/funder, who has granted medRxiv a license to display the preprint in perpetuity. It is made available under a CC-BY-NC-ND 4.0 International license .

B) This leads to the presence of genomic patterns of Identity-by-Descent (IBD) haplotype sharing across distantly related patients. These haplotypes have been co-inherited from a recent, shared common ancestor at some point in recent genealogical history. IBD can be inferred from phased genotype data and clustered into homologous groups. C) Different coloured IBD-haplotypes represent different groups of IBD that have each been co-inherited identically by multiple individuals and that can be clustered together according to homology. D) Population-scale linkage mapping performed via Phenome-Wide Association (PheWAS) by extracting phenotypes from the Electronic Health Records (EHR) in the form of ICD-9 billing codes, and systematically testing for association between all IBD-haplotype clusters and all ICD-9 code outcomes.

A

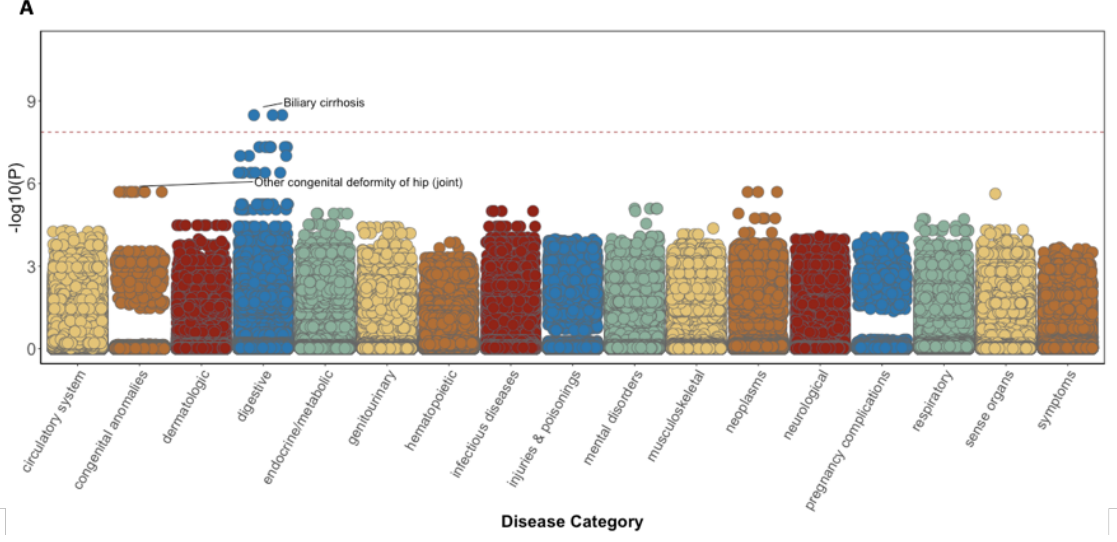

B

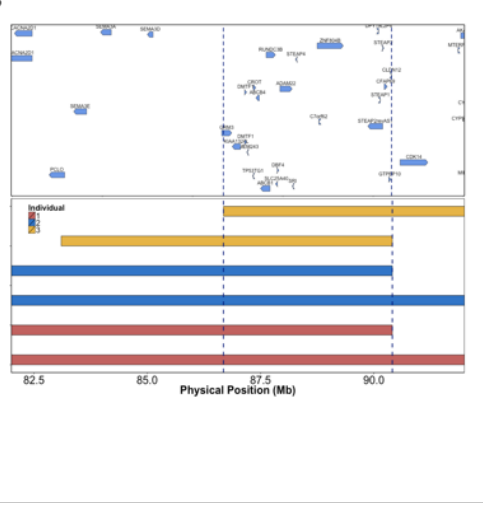

Figure 2. A) Phenome-Wide Population Scale Linkage of IBD Haplotypes in Puerto Ricans. PheWAS of recessive IBD-haplotypes against N=4880 ICD-9 billing codes revealed an association between "biliary cirrhosis" and an IBD-haplotype at 7q21.12. Red-dashed line represents the study-wide significance threshold. We also observed a suggestive association signal between an IBD-haplotype at 9q32 and "other congenital deformity of the hip", recapitulating the known signal for Steel Syndrome in Puerto Ricans at that locus. B) The minimum shared boundary of the IBD-haplotypes shared between all three homozygotes at $7 q 21.12$ spans a highly genic mapping interval of 3.6MB.

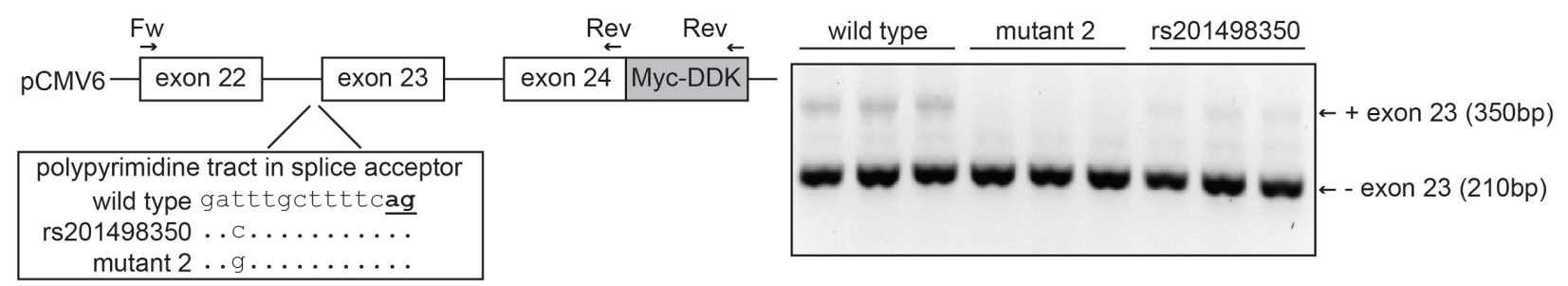


medRxiv preprint doi: https://doi.org/10.1101/2021.03.31.21254662; this version posted April 6, 2021. The copyright holder for this preprint (which was not certified by peer review) is the author/funder, who has granted medRxiv a license to display the preprint in perpetuity. It is made available under a CC-BY-NC-ND 4.0 International license.

Figure 3. $A B C B 4: C .2784-12 T>C$ leads to increased skipping of exon 23. Schematic representation of the approach to study the effect of $A B C B 4: C .2784-12 T>C$ (rs201498350) on $A B C B 4$ splicing. A genomic region containing exons 22 to exons 24 of $A B C B 4$ was cloned into the pCMV6 expression vector using a forward and reverse primer as indicated. The construct harbors the 3' 65bp of exon 22, intron 22 (1,583bp), exon 23 (141bp), intron 23 (2,500bp) and the 5' $51 \mathrm{bp}$ of exon 24 . The location of rs 201498350 in the polypyrimidine tract in the splice acceptor site is indicated. The consensus AG at the -2 and -1 position of the splice acceptor is bold and underlined. The rs201498350 as well as another mutation (mutant 2) were introduced into the pCMV6 vector followed by transfection into HEK-293 cells (triplicate). The result of the RT-PCR with the Fw and Myc-DDK reverse primers is shown as the inverted colors of the ethidium bromide staining of a $2 \%$ agarose gel.

A

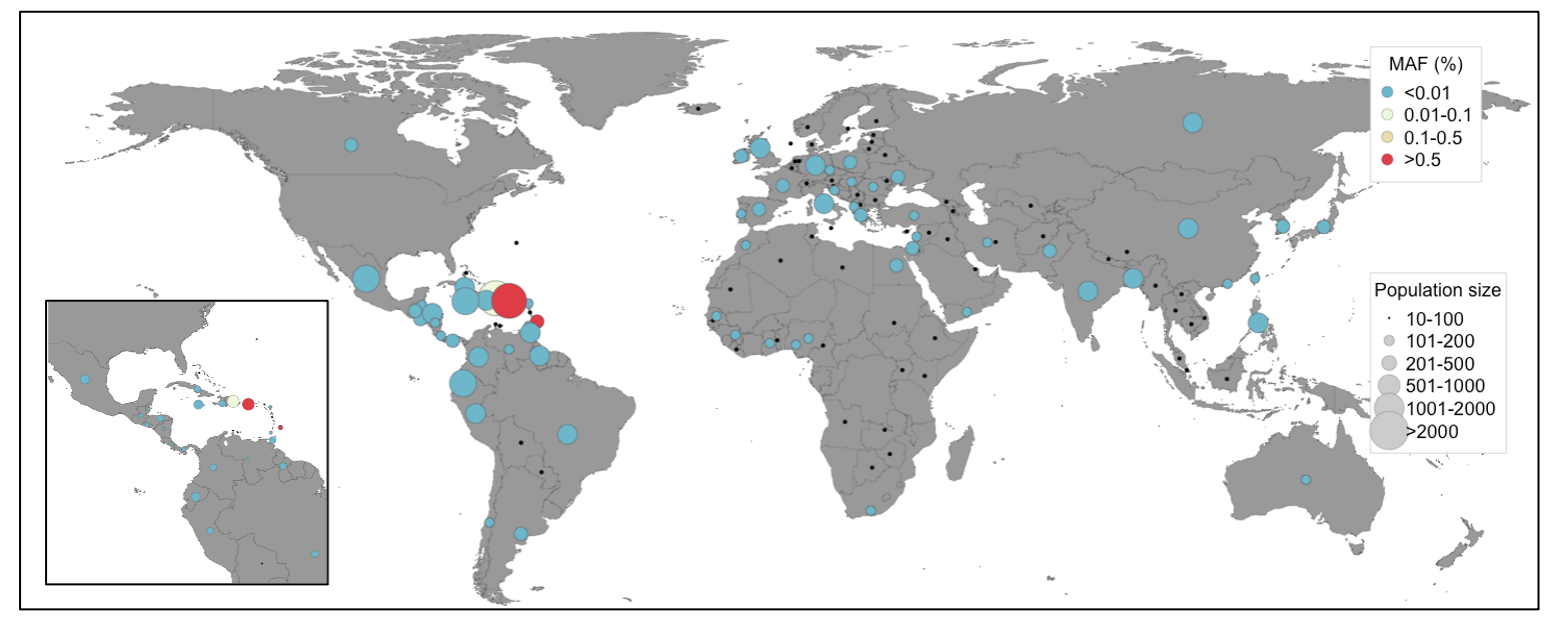

\section{B}
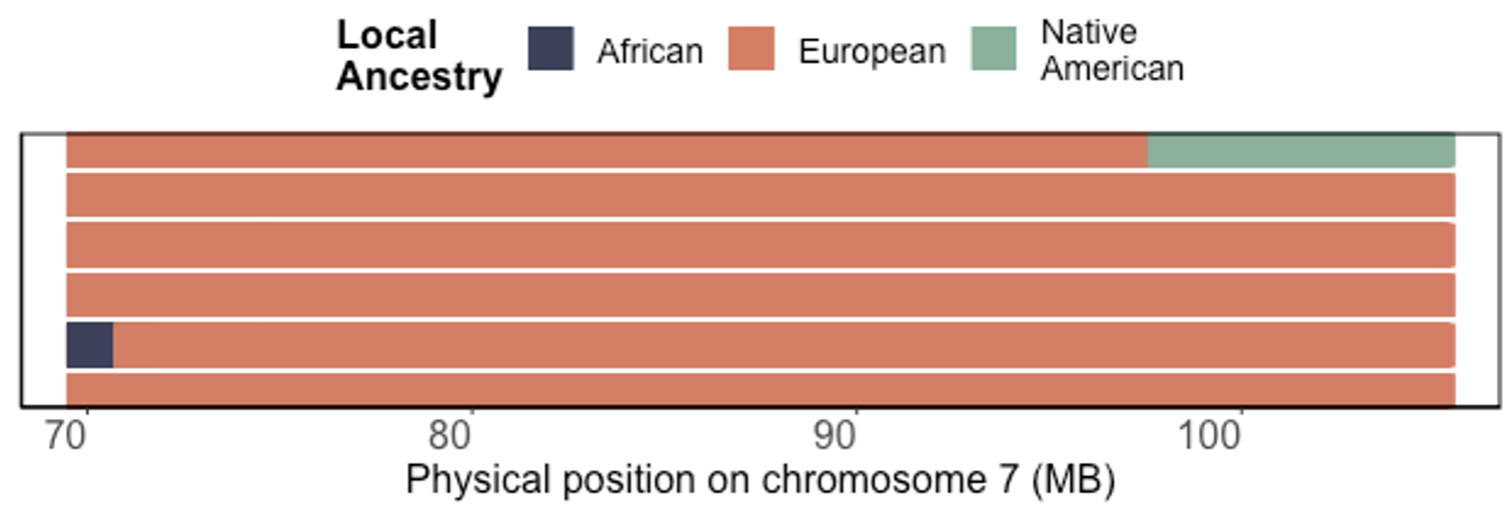
medRxiv preprint doi: https://doi.org/10.1101/2021.03.31.21254662; this version posted April 6, 2021. The copyright holder for this preprint (which was not certified by peer review) is the author/funder, who has granted medRxiv a license to display the preprint in perpetuity.

Figure 4. (A) Minor Allele Frequency of $A B C B 4: C .2784-12 T>C$ by geographic country of birth across $\mathrm{N}=134$ countries in $\mathrm{N}=10232$ BioMe participants born outside of the United States. Population screening of $A B C B 4: C .2784-12 T>C$ based on self-reported country of birth reveals segregation to be geographically restricted to the Caribbean, with elevated frequency in Puerto Rico. (B) Local ancestry across the maximum shared boundary of the three homozygotes identified through IBD sharing reveals all two be homozygous for European ancestry across the locus.

\begin{tabular}{|c|c|c|c|c|c|c|c|c|c|c|}
\hline \multirow[b]{2}{*}{$\begin{array}{l}\text { Serum } \\
\text { Measure }\end{array}$} & \multicolumn{2}{|l|}{ Patient A } & \multicolumn{2}{|c|}{ Patient B } & \multicolumn{2}{|c|}{ Patient C } & \multicolumn{2}{|c|}{ Patient D } & \multicolumn{2}{|c|}{ Patient E } \\
\hline & Median (range) & $\mathbf{N}$ & Median (range) & $\mathbf{N}$ & $\begin{array}{l}\text { Median } \\
\text { (range) }\end{array}$ & $\mathbf{N}$ & Median (range) & $\mathbf{N}$ & $\begin{array}{l}\text { Median } \\
\text { (range) }\end{array}$ & $\mathbf{N}$ \\
\hline GGT & 847 & 1 & $64.5(50-127)$ & 8 & $\begin{array}{c}265(255- \\
347)\end{array}$ & 3 & NA & 0 & $144(81-180)$ & 12 \\
\hline ALT & $17.5(5-93)$ & 4 & $27.5(18-52)$ & 18 & $43(22-88)$ & 6 & NA & 0 & $41(21-78)$ & 28 \\
\hline AST & $15.5(11-186)$ & 4 & $68(55-128)$ & 18 & $68(55-128)$ & 6 & NA & 0 & $64.5(37-93)$ & 28 \\
\hline ALP & $83(66-390)$ & 4 & $554(307-738)$ & 18 & $\begin{array}{c}554(307- \\
738)\end{array}$ & 6 & NA & 0 & $\begin{array}{c}161.5(106- \\
190)\end{array}$ & 28 \\
\hline $\begin{array}{l}\text { Bilirubin } \\
\text { (Total) }\end{array}$ & $1.25(0.2-10.5)$ & 4 & $5.4(0.2-6.6)$ & 18 & $5.4(0.2-6.6)$ & 7 & NA & 0 & $1.3(0.9-2.5)$ & 31 \\
\hline $\begin{array}{l}\text { Bilirubin } \\
\text { (Direct) }\end{array}$ & $1(0 .-7.4)$ & 3 & $3(1.1-4.1)$ & 8 & $3(1.1-4.1)$ & 3 & NA & 0 & $0.5(0.4-1.1)$ & 18 \\
\hline Platelet Count & $199(131-214)$ & 5 & $86(53-103)$ & 20 & $86(53-103)$ & 3 & 215 & 1 & $77(65-103)$ & 21 \\
\hline Albumin & $3.35(2.5-3.8)$ & 4 & $2.75(2.1-3.2)$ & 18 & $\begin{array}{c}2.75(2.1- \\
3.2)\end{array}$ & 6 & NA & 0 & $3.1(2.6-3.6)$ & 31 \\
\hline
\end{tabular}


medRxiv preprint doi: https://doi.org/10.1101/2021.03.31.21254662; this version posted April 6, 2021. The copyright holder for this preprint (which was not certified by peer review) is the author/funder, who has granted medRxiv a license to display the preprint in perpetuity.

It is made available under a CC-BY-NC-ND 4.0 International license .

\begin{tabular}{|l|c|c|c|c|c|c|c|c|c|} 
& & & $1.85(1.4-$ & & & \\
INR & $1.1(1-1.3)$ & 3 & $1.85(1.4-2.3)$ & 10 & $2.3)$ & 2 & 1 & 1 & $1.2(65-103)$ \\
\hline
\end{tabular}

Table 1. Summary of outpatient liver enzymes and liver function tests for the five ABCB4:C.2784-12T>C homozygotes.

\begin{tabular}{|c|c|c|c|c|c|}
\hline $\begin{array}{l}\text { ICD-9 } \\
\text { Code }\end{array}$ & Beta & $\begin{array}{l}\text { Standard } \\
\text { Error }\end{array}$ & p-value & ICD-9 Translation & Disease Category \\
\hline 788.62 & 5.69 & 1.73 & 0.00098 & Slowing of urinary stream & genitourinary \\
\hline 574.1 & 1.96 & 0.64 & 0.00222 & $\begin{array}{l}\text { Calculus of gallbladder with other } \\
\text { cholecystitis, without mention of obstruction }\end{array}$ & digestive \\
\hline 724.02 & 1.66 & 0.59 & 0.00465 & Spinal stenosis of lumbar region & musculoskeletal \\
\hline 396.3 & 5.20 & 1.85 & 0.00489 & $\begin{array}{l}\text { Mitral valve insufficiency and aortic valve } \\
\text { insufficiency }\end{array}$ & circulatory system \\
\hline 695.9 & 2.01 & 0.72 & 0.00537 & Unspecified erythematous condition & dermatologic \\
\hline E933.1 & 2.79 & 1.01 & 0.00547 & $\begin{array}{l}\text { Antineoplastic and immunosuppressive drugs } \\
\text { causing adverse effects in therapeutic use }\end{array}$ & injuries \& poisonings \\
\hline 640.03 & 3.34 & 1.22 & 0.00607 & Threatened abortion, antepartum & $\begin{array}{l}\text { pregnancy } \\
\text { complications }\end{array}$ \\
\hline 680.9 & 3.43 & 1.25 & 0.00616 & Carbuncle and furuncle of unspecified site & dermatologic \\
\hline V81.0 & 4.63 & 1.72 & 0.00694 & Screening for Ischemic Heart Disease & NA \\
\hline 249.6 & 2.57 & 0.95 & 0.00704 & $\begin{array}{c}\text { Secondary diabetes mellitus with neurological } \\
\text { manifestations, not stated as uncontrolled, or } \\
\text { unspecified }\end{array}$ & endocrine/metabolic \\
\hline
\end{tabular}

Table 2. Phenome-wide association study of heterozygous carrier status of ABCB4:C.2784$12 T>C$. 
medRxiv preprint doi: https://doi.org/10.1101/2021.03.31.21254662; this version posted April 6, 2021. The copyright holder for this preprint (which was not certified by peer review) is the author/funder, who has granted medRxiv a license to display the preprint in perpetuity.

It is made available under a CC-BY-NC-ND 4.0 International license .

\begin{tabular}{|c|c|c|c|}
\hline Phenotype & Measures & Beta & p-value \\
\hline Albumin & 4309 & -0.01 & 0.956 \\
\hline Alkaline Phosphatase & 4347 & 0.19 & 0.091 \\
\hline Alanine Transaminase & 4367 & 0.39 & $0.0007^{* *}$ \\
\hline Aspartate Transaminase & 4288 & 0.36 & $0.002^{* *}$ \\
\hline Direct Bilirubin & 2875 & 0.08 & 0.566 \\
\hline Total Bilirubin & 4331 & 0.03 & 0.781 \\
\hline Gamma-Glutamyl Transferase & 1474 & 0.41 & $0.027^{*}$ \\
\hline International Normalized Ratio & 2681 & -0.03 & 0.838 \\
\hline Blood Platelet Count & 4250 & -0.01 & 0.924 \\
\hline
\end{tabular}

Table 3. Association study of heterozygous carrier status of $A B C B 4: C .2784-12 T>C$ with nine outpatient serum measures.

\begin{tabular}{|cccc|}
\hline Count & Total from country & Carrier rate & Country \\
\hline 98 & 379058 & $0.026 \%(0.021-0.036 \%)$ & England \\
49 & 39110 & $0.125 \%(0.095-0.166 \%)$ & Scotland \\
6 & 21563 & $0.028 \%(0.013-0.060 \%)$ & Wales \\
3 & 4785 & $0.063 \%(0.021-0.184 \%)$ & Republic of Ireland \\
2 & 2989 & $0.067 \%(0.018-0.243 \%)$ & Northern Ireland \\
1 & 196 & $0.510 \%(0.090-2.83 \%)$ & Austria \\
1 & 271 & $0.369 \%(0.065-2.060 \%)$ & Brazil \\
1 & 730 & $0.137 \%(0.024-0.771 \%)$ & Canada \\
1 & 853 & $0.117 \%(0.021-0.661 \%)$ & France \\
1 & 8 & NA & Isle of Man \\
1 & 686 & $0.145 \%(0.025-0.821 \%)$ & New Zealand \\
1 & 636 & $0.157 \%(0.028-0.885 \%)$ & Poland \\
\hline
\end{tabular}

Table 4. Minor allele count and carrier rate for $N=165$ copies of $A B C B 4: C .2784-12 T>C$ by country of birth in the UK Biobank. 
medRxiv preprint doi: https://doi.org/10.1101/2021.03.31.21254662; this version posted April 6, 2021. The copyright holder for this preprint (which was not certified by peer review) is the author/funder, who has granted medRxiv a license to display the preprint in perpetuity.

It is made available under a CC-BY-NC-ND 4.0 International license .

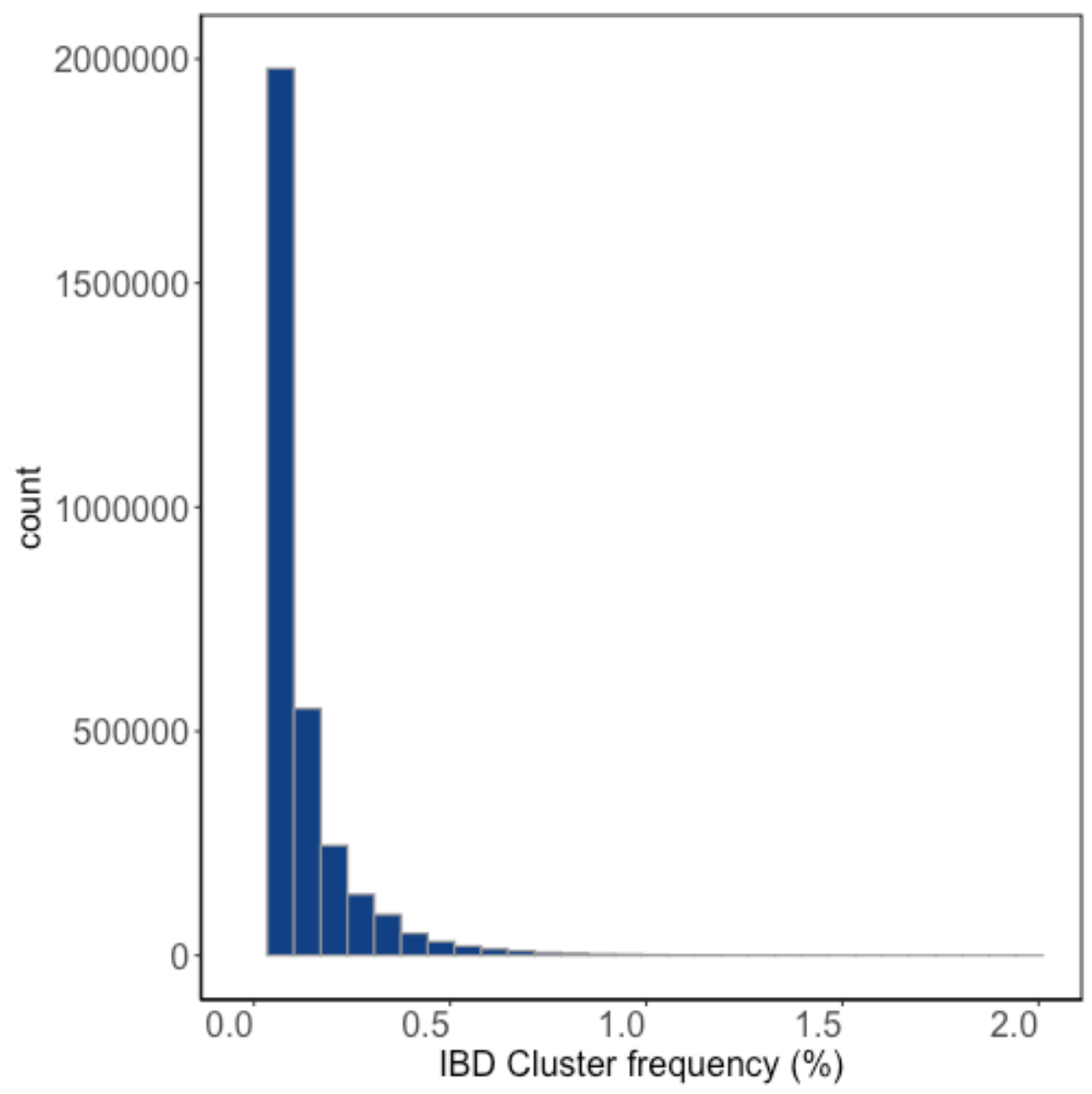

Supplementary Figure 1. Site frequency spectrum of homologous IBD clusters in BioMe PR. 


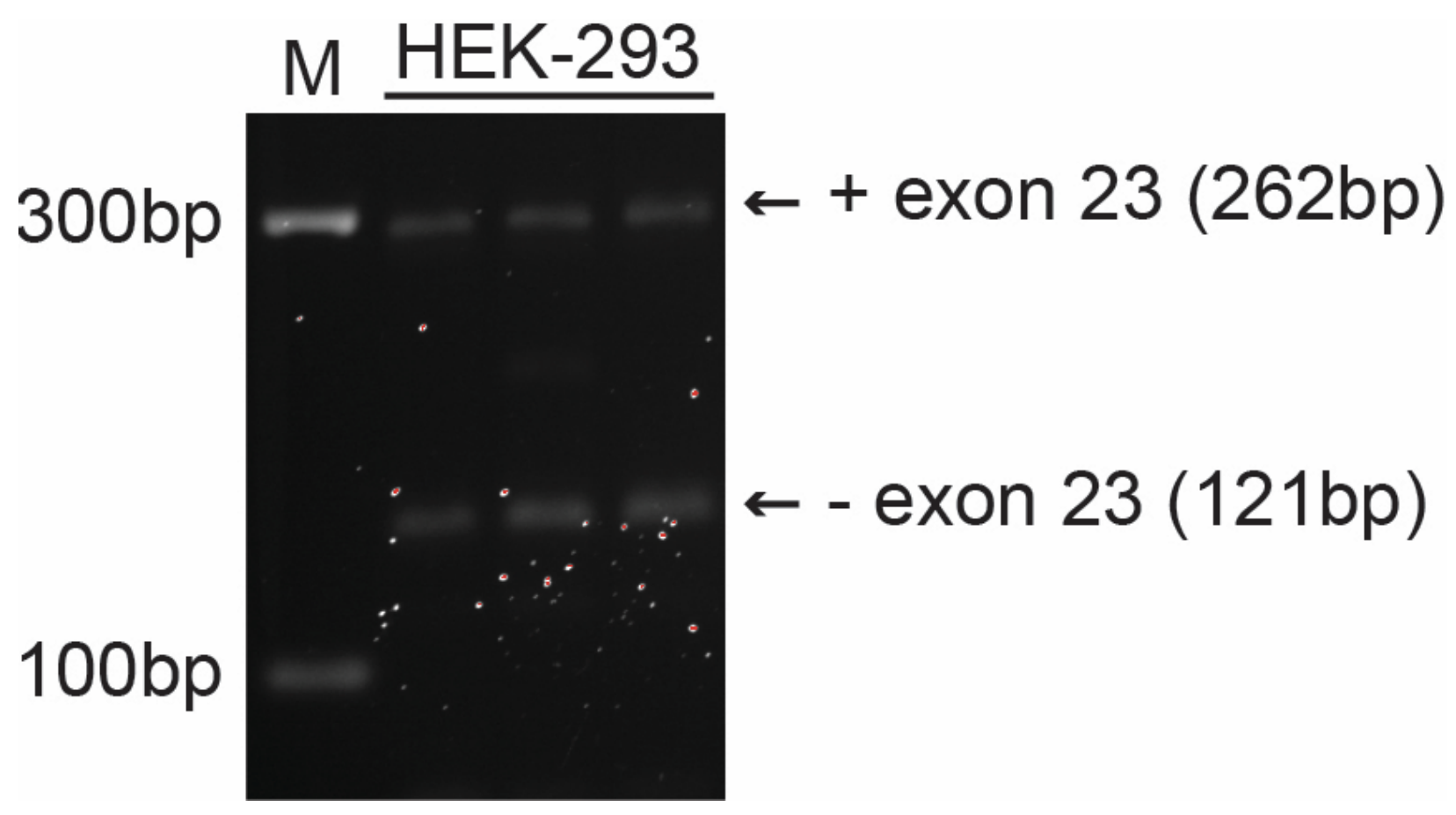

Supplementary Figure 2. Natural occurrence of ABCB4 cDNA lacking exon 23 in HEK-293 cells. $A B C B 4$ cDNA fragments were amplified from HEK-293 cDNA using primers targeting exon 22 and exon 24. The first lane contains the molecular-weight size marker. The size of the cDNA fragments are indicated. The cDNA fragments run at a slightly larger molecular-weight because the primers were tagged with additional nucleotides for cloning purposes. 

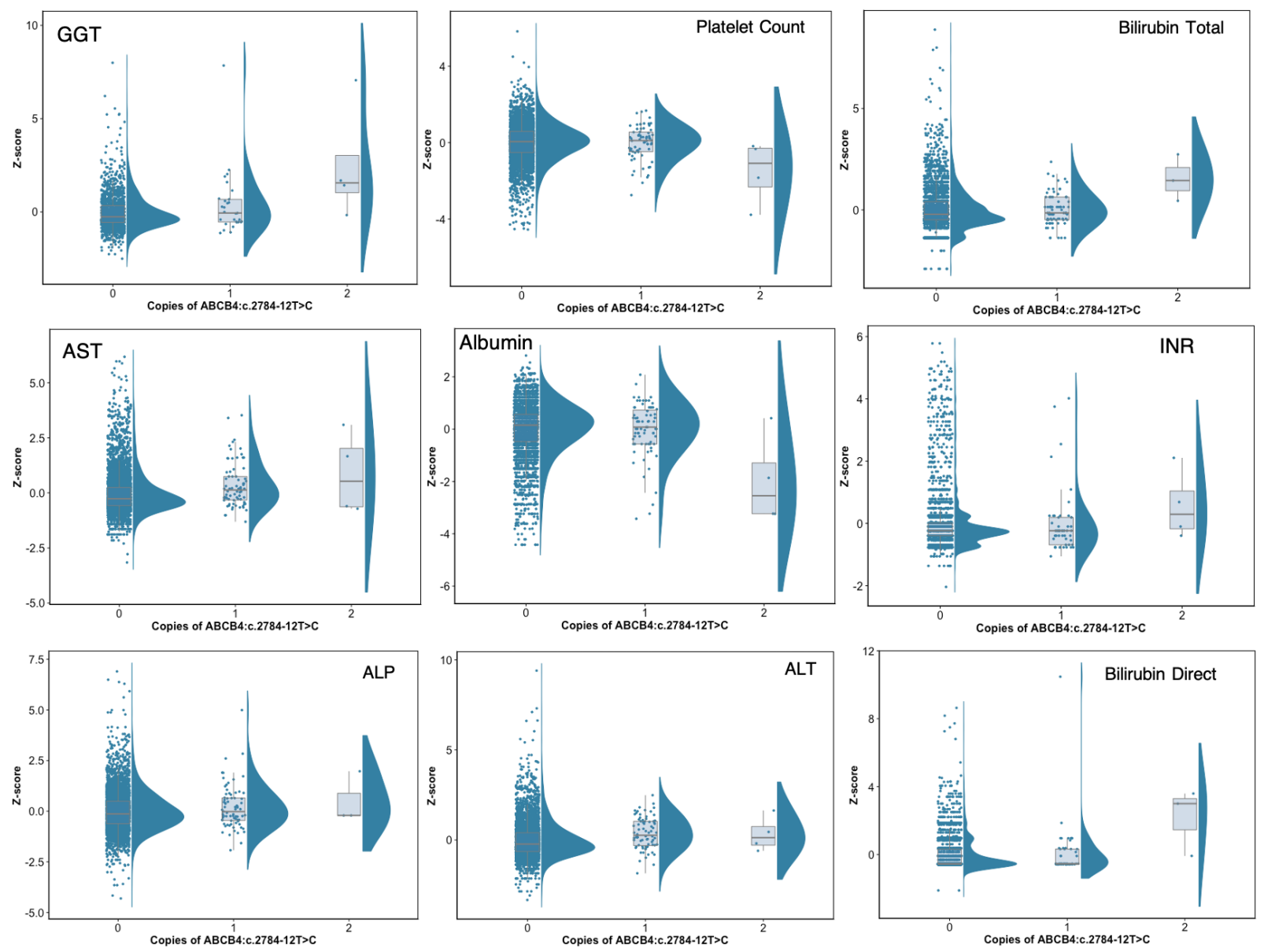

Supplementary Figure 3. Distributions of Z-scores for outpatient values for nine serum measures in Puerto Rican ancestry BioMe participants, stratified by ABCB4:C.2784-12T>C carrier status.

\begin{tabular}{|l|l|l|}
\hline & IBD Carrier & IBD Non-Carrier \\
\hline Exome Carrier & 50 & 23 \\
\hline Exome Non-Carrier & 11 & 4248 \\
\hline
\end{tabular}

Supplementary Table 3. Concordance between being heterozygous for the discovery IBDhaplotype and $A B C B$ 4:c.2784-12 $T>C$ carrier status among PR ancestry individuals present in both the genotype and exome sequence data. 
medRxiv preprint doi: https://doi.org/10.1101/2021.03.31.21254662; this version posted April 6, 2021. The copyright holder for this preprint (which was not certified by peer review) is the author/funder, who has granted medRxiv a license to display the preprint in perpetuity. It is made available under a CC-BY-NC-ND 4.0 International license .

\section{References}

1. Donahue RP, Bias WB, Renwick JH, McKusick VA. Probable assignment of the Duffy blood group locus to chromosome 1 in man. Proc Natl Acad Sci U S A. 1968;61: 949-955.

2. McKusick VA. Current trends in mapping human genes. FASEB J. 1991;5: 12-20.

3. Claussnitzer M, Cho JH, Collins R, Cox NJ, Dermitzakis ET, Hurles ME, et al. A brief history of human disease genetics. Nature. 2020;577: 179-189.

4. Biesecker LG, Green RC. Diagnostic clinical genome and exome sequencing. The New England journal of medicine. 2014. p. 1170.

5. Turro E, Astle WJ, Megy K, Gräf S, Greene D, Shamardina O, et al. Whole-genome sequencing of patients with rare diseases in a national health system. Nature. 2020;583: 96-102.

6. Abul-Husn NS, Manickam K, Jones LK, Wright EA, Hartzel DN, Gonzaga-Jauregui C, et al. Genetic identification of familial hypercholesterolemia within a single U.S. health care system. Science. 2016;354. doi:10.1126/science.aaf7000

7. Popejoy AB, Fullerton SM. Genomics is failing on diversity. Nature. 2016. pp. 161-164.

8. Abul-Husn NS, Kenny EE. Personalized Medicine and the Power of Electronic Health Records. Cell. 2019;177: 58-69.

9. Van Hout CV, Tachmazidou I, Backman JD, Hoffman JD, Liu D, Pandey AK, et al. Exome sequencing and characterization of 49,960 individuals in the UK Biobank. Nature. 2020;586: 749-756.

10. Schwartz MLB, McCormick CZ, Lazzeri AL, Lindbuchler DM, Hallquist MLG, Manickam K, et al. A Model for Genome-First Care: Returning Secondary Genomic Findings to Participants and Their Healthcare Providers in a Large Research Cohort. Am J Hum Genet. 2018;103: 328-337.

11. Browning SR, Browning BL. Identity by descent between distant relatives: detection and applications. Annu Rev Genet. 2012;46: 617-633.

12. Browning SR, Thompson EA. Detecting rare variant associations by identity-by-descent mapping in case-control studies. Genetics. 2012;190: 1521-1531.

13. Gauvin H, Moreau C, Lefebvre J-F, Laprise C, Vézina H, Labuda D, et al. Genome-wide patterns of identity-by-descent sharing in the French Canadian founder population. Eur J Hum Genet. 2014;22: 814-821.

14. Thompson EA. Identity by descent: variation in meiosis, across genomes, and in populations. Genetics. 2013;194: 301-326.

15. Te Meerman GJ, Van der Meulen MA, Sandkuijl LA. Perspectives of identity by descent (IBD) mapping in founder populations. Clin Exp Allergy. 1995;25 Suppl 2: 97-102.

16. Houwen RH, Baharloo S, Blankenship K, Raeymaekers P, Juyn J, Sandkuijl LA, et al. 
medRxiv preprint doi: https://doi.org/10.1101/2021.03.31.21254662; this version posted April 6, 2021. The copyright holder for this preprint (which was not certified by peer review) is the author/funder, who has granted medRxiv a license to display the preprint in perpetuity. It is made available under a CC-BY-NC-ND 4.0 International license .

Genome screening by searching for shared segments: mapping a gene for benign recurrent intrahepatic cholestasis. Nat Genet. 1994;8: 380-386.

17. Bastarache L, Hughey JJ, Hebbring S, Marlo J, Zhao W, Ho WT, et al. Phenotype risk scores identify patients with unrecognized Mendelian disease patterns. Science. 2018;359: 1233-1239.

18. Belbin GM, Odgis J, Sorokin EP, Yee M-C, Kohli S, Glicksberg BS, et al. Genetic identification of a common collagen disease in puerto ricans via identity-by-descent mapping in a health system. Elife. 2017;6. doi:10.7554/eLife.25060

19. Denny JC, Ritchie MD, Basford MA, Pulley JM, Bastarache L, Brown-Gentry K, et al. PheWAS: demonstrating the feasibility of a phenome-wide scan to discover gene-disease associations. Bioinformatics. 2010;26: 1205-1210.

20. Reichert MC, Lammert F. ABCB4 Gene Aberrations in Human Liver Disease: An Evolving Spectrum. Semin Liver Dis. 2018;38: 299-307.

21. Belbin GM, Wenric S, Cullina S, Glicksberg BS, Moscati A, Wojcik GL, et al. Towards a fine-scale population health monitoring system. Cold Spring Harbor Laboratory. 2019. p. 780668. doi:10.1101/780668

22. Rentzsch P, Witten D, Cooper GM, Shendure J, Kircher M. CADD: predicting the deleteriousness of variants throughout the human genome. Nucleic Acids Res. 2019;47: D886-D894.

23. Jaganathan K, Kyriazopoulou Panagiotopoulou S, McRae JF, Darbandi SF, Knowles D, Li YI, et al. Predicting Splicing from Primary Sequence with Deep Learning. Cell. 2019;176: 535-548.e24.

24. Koch L. Exploring human genomic diversity with gnomAD. Nature reviews. Genetics. 2020. p. 448.

25. Karczewski KJ, Francioli LC, Tiao G, Cummings BB, Alföldi J, Wang Q, et al. The mutational constraint spectrum quantified from variation in 141,456 humans. Nature. 2020;581: 434-443.

26. Moreno-Estrada A, Gravel S, Zakharia F, McCauley JL, Byrnes JK, Gignoux CR, et al. Reconstructing the population genetic history of the Caribbean. PLoS Genet. 2013;9: e1003925.

27. Sticova E, Jirsa M. ABCB4 disease: Many faces of one gene deficiency. Ann Hepatol. 2020;19: 126-133.

28. Stättermayer AF, Halilbasic E, Wrba F, Ferenci P, Trauner M. Variants in ABCB4 (MDR3) across the spectrum of cholestatic liver diseases in adults. J Hepatol. 2020;73: 651-663.

29. Lincke CR, Smit JJ, van der Velde-Koerts T, Borst $P$. Structure of the human MDR3 gene and physical mapping of the human MDR locus. J Biol Chem. 1991;266: 5303-5310.

30. van Helvoort A, Smith AJ, Sprong H, Fritzsche I, Schinkel AH, Borst P, et al. MDR1 Pglycoprotein is a lipid translocase of broad specificity, while MDR3 P-glycoprotein specifically translocates phosphatidylcholine. Cell. 1996;87: 507-517. 
medRxiv preprint doi: https://doi.org/10.1101/2021.03.31.21254662; this version posted April 6, 2021. The copyright holder for this preprint

(which was not certified by peer review) is the author/funder, who has granted medRxiv a license to display the preprint in perpetuity. It is made available under a CC-BY-NC-ND 4.0 International license .

31. Smit JJ, Schinkel AH, Oude Elferink RP, Groen AK, Wagenaar E, van Deemter L, et al. Homozygous disruption of the murine mdr2 P-glycoprotein gene leads to a complete absence of phospholipid from bile and to liver disease. Cell. 1993;75: 451-462.

32. Morita S-Y, Terada T. Molecular mechanisms for biliary phospholipid and drug efflux mediated by ABCB4 and bile salts. Biomed Res Int. 2014;2014: 954781.

33. Davit-Spraul A, Gonzales E, Baussan C, Jacquemin E. The spectrum of liver diseases related to ABCB4 gene mutations: pathophysiology and clinical aspects. Semin Liver Dis. 2010;30: 134-146.

34. de Vree JM, Jacquemin E, Sturm E, Cresteil D, Bosma PJ, Aten J, et al. Mutations in the MDR3 gene cause progressive familial intrahepatic cholestasis. Proc Natl Acad Sci U S A. 1998;95: 282-287.

35. Degiorgio D, Colombo C, Seia M, Porcaro L, Costantino L, Zazzeron L, et al. Molecular characterization and structural implications of 25 new ABCB4 mutations in progressive familial intrahepatic cholestasis type 3 (PFIC3). Eur J Hum Genet. 2007;15: 1230-1238.

36. Deleuze JF, Jacquemin E, Dubuisson C, Cresteil D, Dumont M, Erlinger S, et al. Defect of multidrug-resistance 3 gene expression in a subtype of progressive familial intrahepatic cholestasis. Hepatology. 1996;23: 904-908.

37. Gotthardt D, Runz H, Keitel V, Fischer C, Flechtenmacher C, Wirtenberger M, et al. A mutation in the canalicular phospholipid transporter gene, ABCB4, is associated with cholestasis, ductopenia, and cirrhosis in adults. Hepatology. 2008;48: 1157-1166.

38. Ziol M, Barbu V, Rosmorduc O, Frassati-Biaggi A, Barget N, Hermelin B, et al. ABCB4 heterozygous gene mutations associated with fibrosing cholestatic liver disease in adults. Gastroenterology. 2008;135: 131-141.

39. Wasmuth HE, Glantz A, Keppeler H, Simon E, Bartz C, Rath W, et al. Intrahepatic cholestasis of pregnancy: the severe form is associated with common variants of the hepatobiliary phospholipid transporter ABCB4 gene. Gut. 2007;56: 265-270.

40. Anzivino C, Odoardi MR, Meschiari E, Baldelli E, Facchinetti F, Neri I, et al. ABCB4 and $A B C B 11$ mutations in intrahepatic cholestasis of pregnancy in an Italian population. Dig Liver Dis. 2013;45: 226-232.

41. Johnston RC, Stephenson ML, Nageotte MP. Novel heterozygous ABCB4 gene mutation causing recurrent first-trimester intrahepatic cholestasis of pregnancy. J Perinatol. 2014;34: 711-712.

42. Müllenbach R, Linton KJ, Wiltshire S, Weerasekera N, Chambers J, Elias E, et al. ABCB4 gene sequence variation in women with intrahepatic cholestasis of pregnancy. $\mathrm{J}$ Med Genet. 2003;40: e70.

43. Lang C, Meier Y, Stieger B, Beuers U, Lang T, Kerb R, et al. Mutations and polymorphisms in the bile salt export pump and the multidrug resistance protein 3 associated with druginduced liver injury. Pharmacogenet Genomics. 2007;17: 47-60.

44. Rosmorduc O, Poupon R. Low phospholipid associated cholelithiasis: association with 
medRxiv preprint doi: https://doi.org/10.1101/2021.03.31.21254662; this version posted April 6, 2021. The copyright holder for this preprint (which was not certified by peer review) is the author/funder, who has granted medRxiv a license to display the preprint in perpetuity. It is made available under a CC-BY-NC-ND 4.0 International license .

mutation in the MDR3/ABCB4 gene. Orphanet J Rare Dis. 2007;2: 29.

45. Vujkovic M, Ramdas S, Lorenz KM, Schneider CV, Park J, Lee KM, et al. A genome-wide association study for nonalcoholic fatty liver disease identifies novel genetic loci and traitrelevant candidate genes in the Million Veteran Program. medRxiv. 2021; 2020.12.26.20248491.

46. Kanai M, Akiyama M, Takahashi A, Matoba N, Momozawa Y, Ikeda M, et al. Genetic analysis of quantitative traits in the Japanese population links cell types to complex human diseases. Nat Genet. 2018;50: 390-400.

47. Gudbjartsson DF, Helgason H, Gudjonsson SA, Zink F, Oddson A, Gylfason A, et al. Largescale whole-genome sequencing of the Icelandic population. Nat Genet. 2015;47: 435-444.

48. Lammert F, Hochrath K. A letter on ABCB4 from Iceland: On the highway to liver disease. Clin Res Hepatol Gastroenterol. 2015;39: 655-658.

49. Soler DM, Del Valle Al, Fernandez-Lube D, Shneider BL. Cross-Sectional Analysis of Progressive Familial Intrahepatic Cholestasis in Puerto Rican Children. P R Health Sci J. 2016;35: 220-223.

50. Vishnu A, Belbin GM, Wojcik GL, Bottinger EP, Gignoux CR, Kenny EE, et al. The role of country of birth, and genetic and self-identified ancestry, in obesity susceptibility among African and Hispanic Americans. Am J Clin Nutr. 2019;110: 16-23.

51. Purcell S, Neale B, Todd-Brown K, Thomas L, Ferreira MAR, Bender D, et al. PLINK: A Tool Set for Whole-Genome Association and Population-Based Linkage Analyses. The American Journal of Human Genetics. 2007. pp. 559-575. doi:10.1086/519795

52. Chang CC, Chow CC, Tellier LC, Vattikuti S, Purcell SM, Lee JJ. Second-generation PLINK: rising to the challenge of larger and richer datasets. Gigascience. 2015;4: 7.

53. Loh P-R, Danecek P, Palamara PF, Fuchsberger C, A Reshef $Y, K$ Finucane $H$, et al. Reference-based phasing using the Haplotype Reference Consortium panel. Nat Genet. 2016;48: 1443-1448.

54. Roshyara NR, Scholz M. fcGENE: a versatile tool for processing and transforming SNP datasets. PLoS One. 2014;9: e97589.

55. Gusev A, Lowe JK, Stoffel M, Daly MJ, Altshuler D, Breslow JL, et al. Whole population, genome-wide mapping of hidden relatedness. Genome Res. 2009;19: 318-326.

56. Rosvall M, Bergstrom CT. Maps of random walks on complex networks reveal community structure. Proc Natl Acad Sci U S A. 2008;105: 1118-1123.

57. Rosvall M, Axelsson D, Bergstrom CT. The map equation. The European Physical Journal Special Topics. 2009. pp. 13-23. doi:10.1140/epjst/e2010-01179-1

58. Gusev A, Kenny EE, Lowe JK, Salit J, Saxena R, Kathiresan S, et al. DASH: A Method for Identical-by-Descent Haplotype Mapping Uncovers Association with Recent Variation. The American Journal of Human Genetics. 2011. pp. 706-717. doi:10.1016/j.ajhg.2011.04.023

59. Dey R, Schmidt EM, Abecasis GR, Lee S. A Fast and Accurate Algorithm to Test for Binary 
medRxiv preprint doi: https://doi.org/10.1101/2021.03.31.21254662; this version posted April 6, 2021. The copyright holder for this preprint

(which was not certified by peer review) is the author/funder, who has granted medRxiv a license to display the preprint in perpetuity.

It is made available under a CC-BY-NC-ND 4.0 International license.

Phenotypes and Its Application to PheWAS. Am J Hum Genet. 2017;101: 37-49.

60. Linderman MD, Brandt T, Edelmann L, Jabado O, Kasai Y, Kornreich R, et al. Analytical validation of whole exome and whole genome sequencing for clinical applications. BMC Med Genomics. 2014;7: 20.

61. Zhou W, Nielsen JB, Fritsche LG, Dey R, Gabrielsen ME, Wolford BN, et al. Efficiently controlling for case-control imbalance and sample relatedness in large-scale genetic association studies. Nat Genet. 2018;50: 1335-1341. 